\title{
Asymmetric reactions catalyzed by chiral titanium complexes
}

\author{
Fuxue Chen, ${ }^{\mathrm{b}}$ Xiaoming Feng, ${ }^{\text {* }}$ Yaozhong Jiang \\ ${ }^{a}$ Sichuan Key Laboratory of Green Chemistry and Technology, The Faculty of Chemistry, \\ Sichuan University, Chengdu 610064, China \\ ${ }^{b}$ Chengdu Institute of Organic Chemistry, Chinese Academy of Sciences, \\ Chengdu 610041, China \\ E-mail: xmfeng@pridns.scu.edu.cn
}

\section{Dedicated to Professor Zhi-Tang Huang on the occasion of his $75^{\text {th }}$ birthday}

(received 13 Sep 02; accepted 04 Nov 02; published on the web 23 Nov 02)

\begin{abstract}
This presentation reviewed some of our recent progress in asymmetric reactions catalyzed by chiral Ti(IV) complexes, including asymmetric oxa-Diels-Alder reaction(up to 99\%ee), asymmetric oxidation of sulfides for sulfoxides (up to $96 \%$ ee), enantioselective silylcyanation of aldehydes (up to $87 \%$ ee) and ketones (up to $69 \%$ ee). The influence of ligand structure, substrate, amount of catalyst, counter ion, solvent, temperature, and other conditions on the reactivity and selectivity were discussed. Some mechanistic insights were also presented.
\end{abstract}

Keywords: Asymmetric reactions, catalysis, chiral titanium complexes

\section{Introduction}

Asymmetry is one of the general features of nature. Chiral molecules play essential roles in physiological process of life, as well as in high-technical fields, owing to its unique physical and biochemical properties. In the last decades, brilliant achievements have been made to provide optically pure or enantiomer-enriched chemicals by employ-ing specific ligand-metal complex, as a remarkable consequence of the coordination chemistry of transition metals, ${ }^{1,2 a}$ to catalyze or promote some asymmetric reactions. Herein, we reviewed our recent progress in asymmetric reactions catalyzed by chiral titanium complexes.

Transition metal titanium shows a special electronic configuration in the atomic orbit and coordination behavior. Titanium chemistry has been highly developed, ${ }^{2 \mathrm{a}-\mathrm{b}}$ and titanium has also been extensively applied to asymmetric synthesis as Lewis acid. ${ }^{2 \mathrm{c}-\mathrm{f}}$ Funded by National Natural Science Foundation of China, we have enriched the titanium methodology and exploited some novel chiral Ti(IV) complexes on asymmetric reactions, ${ }^{3}$ such as silylcyanation of aldehydes, ${ }^{4}$ oxidation of sulfides, ${ }^{5}$ hetero-Diels-Alder reaction, ${ }^{6}$ and silylcyanation of ketones. ${ }^{7}$ 


\section{Results and Discussion}

\section{Asymmetric silylcyanation of aldehydes}

Optically active cyanohydrins are widely used in pesticide and drugs synthesis as fundamental fine chemicals and versatile inter-mediates in organic synthesis. ${ }^{8}$ Both the enzyme method and enantioselective addition of trimethylsilylcyanide (TMSCN) to aldehydes can produce the cyanohydrins, but the latter has received more and more attention in the past 10 years (Scheme $1)$.




2a $\mathrm{R}_{1}=\mathrm{R}_{2}=\mathrm{H}$

2b $\mathrm{R}_{1}=\mathrm{R}_{2}=\mathrm{Bu}^{\mathrm{t}}$

2c $\mathrm{R}_{1}=\mathrm{Bn}, \mathrm{R}_{2}=\mathrm{Me}$

2d $\mathrm{R}_{1}=\mathrm{MeO}, \mathrm{R}_{2}=\mathrm{H}$

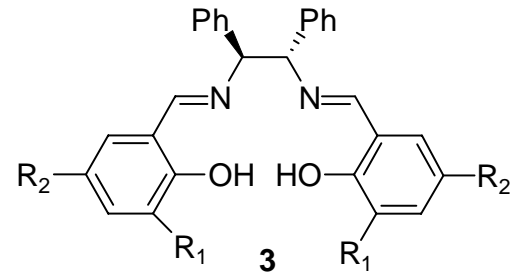

3a $\mathrm{R}_{1}=\mathrm{R}_{2}=\mathrm{Bu}^{\mathrm{t}} \quad$ 3e $\mathrm{R}_{1}=\mathrm{H}, \mathrm{R}_{2}=\mathrm{NO}_{2}$

3b $\mathrm{R}_{1}=\mathrm{Bn}, \mathrm{R}_{2}=\mathrm{Me}$ 3f $\mathrm{R}_{1}=\mathrm{H}, \mathrm{R}_{2}=\mathrm{Br}$

3c $\mathrm{R}_{1}=\mathrm{Me}, \mathrm{R}_{2}=\mathrm{H} \quad 3 \mathrm{~g} \mathrm{R} \mathrm{R}_{1}=\mathrm{H}, \mathrm{R}_{2}=\mathrm{Cl}$

3d $\mathrm{R}_{1}=\mathrm{R}_{2}=\mathrm{H} \quad 3 \mathrm{~h} \mathrm{R}_{1}=\mathrm{H}, \mathrm{R}_{2}=\mathrm{MeO}$

Scheme 1. Silylcyanation of aldehydes and related ligands.

Table 1. Enantioselective addition of TMSCN to aldeyhdes catalyzed by Salen $3 \mathbf{d}-\mathrm{Ti}\left(\mathrm{O}_{i} \operatorname{Pr}\right)_{4}$ complex $^{\mathrm{a}}$

\begin{tabular}{clcccc}
\hline Entry & Aldeyhde & Time $(\mathrm{h})$ & Yield $(\%)^{\mathrm{b}}$ & ee $(\%)$ & Conf. $^{\text {c }}$ \\
\hline 1 & PhCHO & 24 & 72 & $87.1^{\mathrm{d}}$ & $R$ \\
2 & $4-\mathrm{ClC}_{6} \mathrm{H}_{4} \mathrm{CHO}$ & 36 & 76 & $84.0^{\mathrm{e}}$ & $R$ \\
3 & $3-\mathrm{ClC}_{6} \mathrm{H}_{4} \mathrm{CHO}$ & 36 & 69 & $62.1^{\mathrm{e}}$ & $R$ \\
4 & $2-\mathrm{ClC}_{6} \mathrm{H}_{4} \mathrm{CHO}$ & 22 & 80 & $66.0^{\mathrm{d}}$ & $R$ \\
5 & $4-\mathrm{MeC}_{6} \mathrm{H}_{4} \mathrm{CHO}$ & 36 & 60 & $82.0^{\mathrm{e}}$ & $R$ \\
6 & $3-\mathrm{MeC}_{6} \mathrm{H}_{4} \mathrm{CHO}$ & 36 & 69 & $75.5^{\mathrm{e}}$ & $R$ \\
7 & $2-\mathrm{MeC}_{6} \mathrm{H}_{4} \mathrm{CHO}$ & 36 & 68 & $74.1^{\mathrm{e}}$ & $R$ \\
8 & $(E)-\mathrm{C}_{6} \mathrm{H}_{5} \mathrm{CH}=\mathrm{CHCHO}$ & 36 & 77 & $74.6^{\mathrm{e}}$ & $R$ \\
9 & $(E)-\mathrm{CH}_{3} \mathrm{CH}=\mathrm{CHCHO}$ & 36 & 70 & $72.0^{\mathrm{d}}$ & $R$ \\
10 & $\mathrm{n}-\mathrm{C}_{8} \mathrm{H}_{17} \mathrm{CHO}$ & 36 & 58 & $22.4^{\mathrm{d}}$ & $R$ \\
11 & $\left.\mathrm{CH}_{2}=\mathrm{C}_{(\mathrm{CH}}\right) \mathrm{CHO}$ & 36 & 61 & $77.9^{\mathrm{d}}$ & $R$ \\
12 & $\left(\mathrm{CH}_{3}\right)_{3} \mathrm{CCHO}$ & 36 & 85 & $73.0^{\mathrm{d}}$ & $R$ \\
13 & cyclo- $_{6} \mathrm{H}_{11} \mathrm{CHO}$ & 36 & 86 & $40.6^{\mathrm{d}}$ & $R$ \\
\hline
\end{tabular}


${ }^{\mathrm{a}}$ All reactions were performed with $10 \mathrm{~mol} \%$ catalyst in $\mathrm{CH}_{2} \mathrm{Cl}_{2}$ at $-78{ }^{\circ} \mathrm{C}$; ${ }^{\mathrm{b}}$ Isolated yield; ${ }^{\mathrm{c}}$ All absolute configurations were determined by comparison of the sign of optical rotation values with those in literature; ${ }^{d}$ Determined by GC on CYDEX- $\beta$ after derived with trifluoroacetic anhydride or acetyl chloride; ${ }^{\mathrm{e}}$ Determined by HPLC on Chiracel OD after derived with acetyl chloride.

Table 2. Counter ion (CI) effect on the enantioselective addition of TMSCN to benzaldehyde with 3d-Ti $\left(\mathrm{O}_{i} \mathrm{Pr}\right)_{4}$ complex as catalyst ${ }^{\text {a }}$

\begin{tabular}{|c|c|c|c|c|}
\hline $\mathrm{CI}\left(\mathrm{RO}^{-}\right)$ & $\mathrm{CI} /$ catalyst & Time (h) & Yield $(\%)^{b}$ & $e e \%^{c}(\text { conf. })^{d}$ \\
\hline \multirow{2}{*}{$\alpha-\mathrm{C}_{10} \mathrm{H}_{7} \mathrm{O}^{-}$} & $1: 1$ & 18 & 91 & $82.6(R)$ \\
\hline & $2: 1$ & 18 & 90 & $82.6(R)$ \\
\hline \multirow{2}{*}{$\mathrm{O}_{2} \mathrm{~N}-\mathrm{O}^{-}$} & $1: 1$ & 18 & - & $82.6(R)$ \\
\hline & $2: 1$ & 18 & - & $82.6(R)$ \\
\hline & $1: 1$ & 12 & 78 & $80.0(R)$ \\
\hline & $1: 1$ & 12 & 80 & $82.4(R)$ \\
\hline$\left(\mathrm{CH}_{2} \mathrm{CO}_{2}^{-}\right)_{2}$ & $1: 1$ & 12 & 95 & $81.8(R)$ \\
\hline $\mathrm{EtO}^{-}$ & $2: 1$ & 36 & 75 & $84.5(R)$ \\
\hline $\mathrm{n}-\mathrm{BuO}^{-}$ & $2: 1$ & 36 & 70 & $82.6(R)$ \\
\hline
\end{tabular}

${ }^{a}$ All reactions were performed with 10 mol\% catalyst; ${ }^{b}$ Isolated yield; ${ }^{c}$ Determined by GC on chiral CYDEX- $\beta$ after derived with trifluoroacetic anhydride; ${ }^{\mathrm{d}}$ Determined by comparison of the elution order in the GC assay with literature.

Oguni disclosed the first enantioselective silylcyanation of aldehydes catalyzed by $20 \mathrm{~mol} \%$ Schiff base 1-Ti $\left(\mathrm{O}_{i} \mathrm{Pr}\right)_{4}$ complex in $91 \%$ ee (enantiomeric excess). ${ }^{9}$ Jiang observed somewhat different phenomena with ee up to $92 \%$ by making use of Schiff base 2- $\operatorname{Ti}\left(\mathrm{O}_{i} \mathrm{Pr}\right)_{4}$, but the ligands had similar structural backbone. ${ }^{4 a}$

Spurred by these two papers, we made further study on this reaction with 10 mol\% Salen 3$\mathrm{Ti}\left(\mathrm{O}_{i} \mathrm{Pr}\right)_{4}$ as the desired catalysts. ${ }^{4 \mathrm{~b}-\mathrm{d}}$ The effects on enantioselectivity of ligand structure, catalyst amount, reaction temperature, solvent, and substrate generality, were systematic-cally optimized. The best ee value (87\%) was obtained when loading 10 mol\% 3d-Ti( $\left.\mathrm{O}_{i} \mathrm{Pr}\right)_{4}$ complex in $\mathrm{CH}_{2} \mathrm{Cl}_{2}$ at $-78{ }^{\circ} \mathrm{C}$ (Table 1). In addition, the basicity of counter ions (CI) showed more effect on the 
reactivity than on the selectivity (Table 2). Based on these experimental results, a working transition state of the catalyst was proposed as Figure $1 .^{4 \mathrm{c}}$

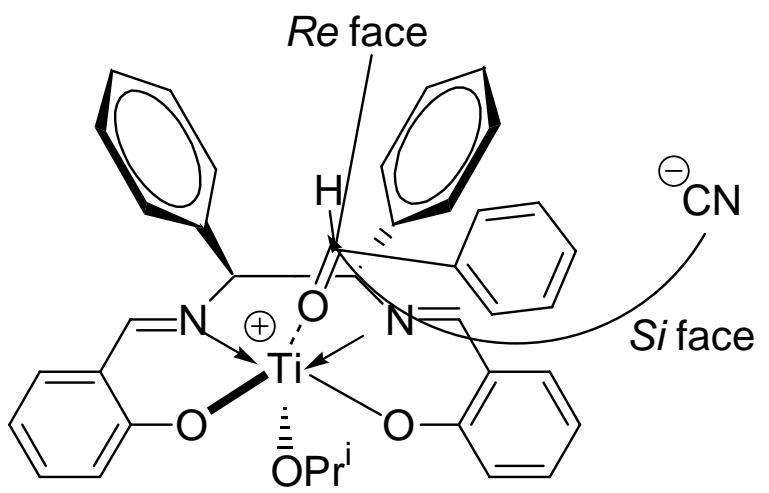

Figure 1. The working transition state for the silylcyanation of aldehydes.

In conclusion, an effective catalyst for asymmetric silylcyanation of aldehydes has been developed. The further modification of the ligand structure should be aimed to extend this catalyst system to asymmetric trimethylsilylcyanation of ketones and imines. ${ }^{10}$

\section{Asymmetric oxidation of sulfides}

Optically active sulfoxide 4 (Scheme 2), a class of important synthons, has been increasingly applied as building blocks to chiral drugs synthesis and as efficient auxiliaries to asymmetric synthesis as well. ${ }^{11}$ Unlike other chiral molecules, sulfoxide 4 could be scarcely extracted from natural materials.

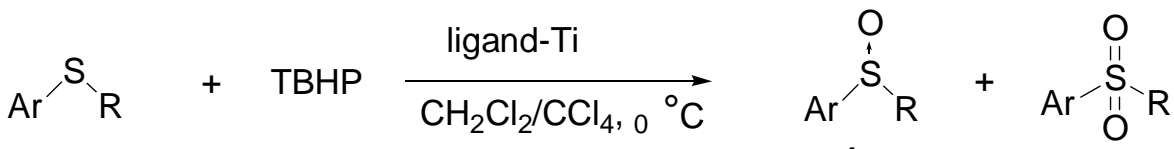

$$
\begin{aligned}
& \text { TBHP = tert-butylhydroperoxide } 4
\end{aligned}
$$

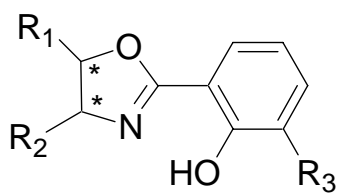

Scheme 2. Oxazolines involved in the asymmetric oxidation of sulfides.

The direct asymmetric oxidation of sulfides approach has received tremendous attention in the area of organic synthesis. Excellent enantioselectivity has been reported by Kagan and other

groups in the past 20 years, ${ }^{12}$ but the ligands were extremely limited within diols and Schiff bases. Oxazoline, another class of important chiral auxiliaries, has been successfully employed in 
the asymmetric Baeyer-Villiger reaction, Mukaiyama aldol reaction, cyclopropanation, etc. Bolm tried out the oxazoline-vanadium (IV) complex on the oxidation of prochiral sulfides, but failed with racemic sulfoxides. ${ }^{13}$

These results prompted us to design some new oxazolines 5 with diverse substitutes and to explore them on the transformation process (Scheme 2). ${ }^{5 \mathrm{a}-\mathrm{e}}$ The highest ee value was recorded $96 \%$ with good yields under the optimized conditions, that is, $5 \mathrm{~mol} \% 5 \mathbf{b}-\mathrm{Ti}\left(\mathrm{O}_{i} \mathrm{Pr}\right)_{4}$ in cosolvent $\left(\mathrm{CH}_{2} \mathrm{Cl}_{2}: \mathrm{CCl}_{4}, 3: 7 \mathrm{v} / \mathrm{v}\right)$ at $0{ }^{\circ} \mathrm{C}$ and TBHP (tert-butylhydroperoxide) as the oxidant (Table $3)$. It is worthwhile to note that the best ee value was partially due to a concomitant kinetic resolution of the generated sulfoxide 4 with $\mathrm{k}_{\mathrm{rel}}=4$ inferior to the value in literature. ${ }^{14}$ The data revealed that the configuration of the chiral carbon atom, which located far away from the titanium center but closely attached to the oxygen atom on the oxazoline ring of the ligand, had stronger influence on the selectivity than the other one.

Table 3. Asymmetric oxidation of sulfides (ArSR) catalyzed by 5b-Ti( $\left(\mathrm{O}_{i} \mathrm{Pr}\right)_{4}$ complex $^{\mathrm{a}}$

\begin{tabular}{|c|c|c|c|c|c|c|c|}
\hline \multirow{2}{*}{ Entry } & \multirow{2}{*}{$\mathrm{Ar}$} & \multirow{2}{*}{$\mathrm{R}$} & \multirow{2}{*}{$\begin{array}{c}\text { Total yield } \\
(\%)\end{array}$} & \multirow{2}{*}{ 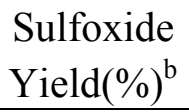 } & \multicolumn{3}{|c|}{ Selectivity } \\
\hline & & & & & sulfoxide : sulfone & $\mathrm{ee}(\%)^{\mathrm{c}}$ & conf. $^{\mathrm{d}}$ \\
\hline 1 & $\mathrm{Ph}$ & $\mathrm{Me}$ & 87 & 33 & $38: 62$ & 80 & $R$ \\
\hline 2 & $\mathrm{Ph}$ & Et & 79 & 32 & $41: 59$ & 72 & $R$ \\
\hline 3 & $4-\mathrm{BrC}_{6} \mathrm{H}_{4}$ & $\mathrm{Me}$ & 78 & 27 & $34: 66$ & 75 & $R$ \\
\hline 4 & $4-\mathrm{MeC}_{6} \mathrm{H}_{4}$ & $\mathrm{Me}$ & 90 & 38 & $42: 58$ & 81 & $R$ \\
\hline 5 & $\mathrm{Ph}$ & $\mathrm{Bn}$ & 86 & 37 & $43: 57$ & 70 & $R$ \\
\hline 6 & pyridyl & $\mathrm{Me}$ & 88 & 50 & $57: 43$ & 21 & $R$ \\
\hline
\end{tabular}

${ }^{\mathrm{a}}$ Conditions: sulfide/ligand $5 \mathbf{b} / \mathrm{Ti}\left(\mathrm{O}_{i} \mathrm{Pr}\right)_{4}=1.0 / 0.1 / 0.05 / 1.0$ (in molar ratio); reaction temperature $0{ }^{\circ} \mathrm{C}$; reaction time $24 \mathrm{~h}$; solvent $\mathrm{CH}_{2} \mathrm{Cl}_{2} / \mathrm{CCl}_{4}(3 / 7, v / v)$; oxidant TBHP(1.4 equiv., $70 \%$ in water); ${ }^{b}$ Isolated yield; ${ }^{c}$ Determined by HPLC on Daicel OB and OD columns. ${ }^{\mathrm{d}}$ The absolute configuration was assigned by comparison with literature values.

In brief, we have first probed and developed a novel effective oxazoline-titanium(IV) catalyst system for the asymmetric oxidation of sulfides. Further study should be focused on the fine tuning of the ligand structure for both selectivity and substrate generality.

\section{Asymmetric trimethylsilylcyanation of ketones}

Tertiary cyanohydrins are versatile synthons for so many optically pure or enantiomeric-enriched chemicals, such as $\beta$-aminoalcohol, $\alpha$-hydroxyl carbonyl compounds. Also, they have been comprehensively used as effective auxiliaries in total synthesis of some natural products and bioactive substances. ${ }^{8}$ Moreover, enantioselective addition of TMSCN to ketones is still a challen-ging process for $\mathrm{C}-\mathrm{C}$ bond formation owing to the sluggish reactivity of the keto group and steric hindrance of ketones.

Belokon reported a Salen-Ti(IV) catalyzed enantioselective addition of TMSCN to ketones (up to $72 \%$ ee). ${ }^{15}$ Shibasaki has first developed a bifunctional phosphine oxide ligand to promote 
the reaction in excellent enantioselectivity (up to $92 \%$ ee). ${ }^{16}$ Deng outlined a method for cyanide addition of aliphatic ketones with cyano-formate, and cinchona alkaloids as catalysts. ${ }^{17}$ Snapper revealed the enantioselective addition of TMSCN to aliphatic and aromatic ketones employing a aluminium-peptide catalyst system together with $4 \AA \mathrm{MS}$ and $\mathrm{MeOH}$ as additives (up to $94 \%$ ee). ${ }^{18}$<smiles>[R]C([R])=O</smiles>



6
6a $\mathrm{R}_{1}=\mathrm{Bn}$,
$\mathrm{R}_{2}=\mathrm{Ph}$
${ }_{6}$ b $\mathrm{R}_{1}=2$ '-picolyl,
$\mathrm{R}_{2}=\mathrm{Ph}$
${ }_{6} \mathrm{C} \quad \mathrm{R}_{1}=3$ '-picolyl,
$\mathrm{R}_{2}=\mathrm{Ph}$
6d $R_{1}=2$-Methoxylbenzyl, $R_{2}=P h$
${ }_{6}$ e $R_{1}=2 '$-picolyl,
$R_{2}=\mid \hat{A}$-naphthyl

\section{Scheme 3}

Enlightened by Shibasaki's bifunctional ligand concept and our previous success in the Strecker reaction ${ }^{10}$ by using chiral $N$-oxides to activate TMSCN, we designed and synthe-sized novel bifunctional ligands 6 with $\mathrm{N}$-oxide moieties from commercially available L-proline (Scheme 3). ${ }^{7}$ Screening experiments proved $\mathbf{6 b}-\mathrm{Ti}\left(\mathrm{O}_{i} \mathrm{Pr}\right)_{4}$ complex at 1:1.2 molar ratio showing the best enantioselectivity (up to $69 \%$ ee) in $\mathrm{CH}_{2} \mathrm{Cl}_{2}$ at $0{ }^{\circ} \mathrm{C}$ (Table 4). The results approved the ligands 6 with $\mathrm{N}$-oxide moieties working mechanistically as bifunc-tional ones, i.e., the metal titanium as Lewis acid and the oxygen in the $\mathrm{N}$-oxide bond as Lewis base to activate the ketone and TMSCN, respectively.

Table 4. Asymmetric silylcyanation of ketones catalyzed by $6 \mathbf{b}-\mathrm{Ti}(\mathrm{OiPr})_{4}$ complex $(1: 1.2$, molar ratio) ${ }^{\mathrm{a}}$

\begin{tabular}{cccccc}
\hline Entry & Ketone & Time(h) & $\begin{array}{c}\text { Isolated } \\
\text { yield }(\%)^{\mathrm{b}}\end{array}$ & ee $\%^{\text {Config. }}$ \\
\hline 1 & acetophenone & 96 & 78 & $54^{\mathrm{c}}$ & $R$ \\
2 & B-acetonaphthone & 96 & 73 & $69^{\mathrm{d}}$ & \\
3 & trans-4-phenyl-3-buten-2-one & 96 & 77 & $25^{\mathrm{d}}$ & \\
4 & benzylacetone & 120 & 87 & $68^{\mathrm{d}}$ & \\
5 & $\alpha$-tetralone & 120 & 61 & $30^{\mathrm{c}}$ & \\
6 & 4'-methylacetophenone & 96 & 63 & $41^{\mathrm{c}}$ & \\
7 & 3'-chloroacetophenone & 120 & 76 & $33^{\mathrm{c}}$ & \\
8 & 2'-fluoroactophenone & 96 & 47 & $55^{\mathrm{c}}$ & \\
\hline
\end{tabular}


${ }^{\text {a }}$ All reactions were carried out using $20 \mathrm{~mol} \%$ catalyst in $\mathrm{CH}_{2} \mathrm{Cl}_{2}$ at $0{ }^{\circ} \mathrm{C}$. The substrate concentration was $0.33 \mathrm{M} ;{ }^{\mathrm{b}}$ Isolated yields; ${ }^{\mathrm{c}}$ Determined by GC on Chirasil DEX CB; ${ }^{\mathrm{d}}$ Determined by HPLC on Chiralcel OD; ${ }^{\mathrm{e}}$ Determined by comparison of the elution order in GC and HPLC assay with literature.

Briefly, we have first explored new bifunctional N-oxides as catalysts for the enantioselective trimethylsilylcyanation of ketones with good isolated yields and moderate selectivity. Further efforts should be logically aimed to improve the enantioselectivity and insight into the nature of the catalytic cycle.

\section{Asymmetric hetero-Diels-Alder reaction}

In recent years, hetero-Diels-Alder (HDA) reaction has gained special attention in the context of catalytic enantioselective carbon-carbon bond-forming process. The Lewis acid-catalyzed HDA reaction between Danishe-fsky's dienes and general dienophiles is of particular interest due to its convenient access to six-membered partly saturated heterocycle pyranones, a class of compounds extensively used as starting materials for total synthesis of many natural products and other highly functionalized heterocycles (Scheme 4). ${ }^{19}$

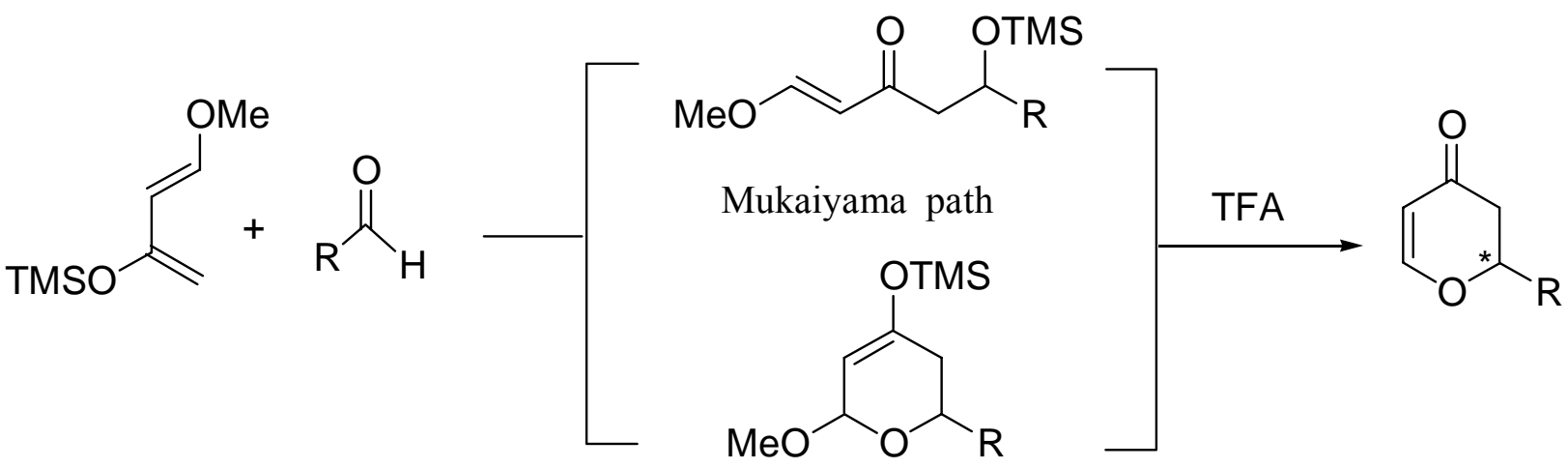

Diels-Alder path

\section{Scheme 4}

We examined different diol ligands and metals, ${ }^{6 \mathrm{~b}}$ and found $20 \mathrm{~mol} \% \mathrm{H}_{8}-\mathrm{BINOL}-\mathrm{Ti}\left(\mathrm{O}_{i} \mathrm{Pr}\right)_{4}$ (1:1.1, molar ratio) complex in toluene at $0{ }^{\circ} \mathrm{C}$ in the presence of $4 \AA \mathrm{MS}$ giving the highest enantioselectivity ( $>99 \%$ ee, Table 5 , entry 11$)$. Interestingly, as the dihedral angle decreasing in the order of $\mathrm{H}_{8}$-BINOL, $\mathrm{H}_{4}$-BINOL, BINOL, both selectivity and reactivity were remarkably deteriorated, respectively, from $97 \%$ ee to $87 \%$ ee and from $92 \%$ to $60 \%$ in chemical yield (Figure 2). This catalytic transformation was mechanistically carried out through the known Mukaiyama aldol intermediate with a six-membered cyclic transition state in line with Keck's report. $^{20}$ 




$(R)-\mathrm{H}_{8}-\mathrm{BINOL}$

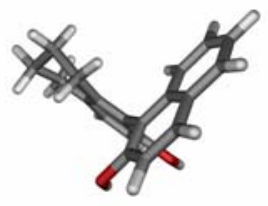

(R)- $\mathrm{H}_{4}-\mathrm{BINOL}$

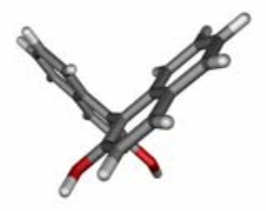

(R)-BINOL

Figure 2. Models of $(R)-\mathrm{H}_{8}-\mathrm{BINOL},(R)-\mathrm{H}_{4}-\mathrm{BINOL},(R)-\mathrm{BINOL}$, and black, carbon; red, oxygen; and grey, hydrogen.

Table 5. Asymmetric oxa-Diels-Alder reactions of aldehydes with Danishefsky`s diene ${ }^{\text {a }}$

\begin{tabular}{|c|c|c|c|c|c|}
\hline Entry & aldehyde & Temp $\left({ }^{\circ} \mathrm{C}\right)$ & Time $(\mathrm{h})$ & Yield $(\%)^{b}$ & ee $(\%)^{\mathrm{c}}$ \\
\hline 1 & $7 a$ & 0 & 24 & 92 & $97^{\mathrm{d}, \mathrm{f}}$ \\
\hline 2 & $\mathbf{7 b}$ & 0 & 24 & 43 & 85 \\
\hline 3 & $7 c$ & 0 & 24 & 71 & 90 \\
\hline 4 & $7 d$ & 0 & 48 & 55 & $90^{\mathrm{e}}$ \\
\hline 5 & $7 e$ & 0 & 24 & 81 & 94 \\
\hline 6 & $7 f$ & 0 & 24 & 81 & 99 \\
\hline 7 & $7 g$ & 0 & 24 & 64 & 95 \\
\hline 8 & $7 \mathbf{h}$ & 0 & 24 & 67 & 97 \\
\hline 9 & $7 \mathbf{i}$ & 0 & 24 & 54 & 98 \\
\hline 10 & $7 \mathbf{j}$ & 0 & 24 & 60 & 99 \\
\hline 11 & $7 \mathbf{k}$ & 0 & 24 & 51 & $>99$ \\
\hline 12 & 71 & 0 & 30 & 78 & $96^{f}$ \\
\hline 13 & $7 \mathrm{~m}$ & 0 & 24 & 55 & $92^{\mathrm{e}}$ \\
\hline 14 & $7 n$ & 0 & 30 & 80 & $98^{\mathrm{f}}$ \\
\hline 15 & 70 & 0 & 48 & 39 & 80 \\
\hline 16 & $7 p$ & $23-25$ & 72 & 57 & 96 \\
\hline 17 & $7 q$ & 0 & 24 & 28 & $35^{\mathrm{e}, \mathrm{f}}$ \\
\hline 18 & $7 r$ & 0 & 24 & 26 & $47^{\mathrm{e}}$ \\
\hline
\end{tabular}

${ }^{\mathrm{a}}$ All reactions were carried out using $20 \mathrm{~mol} \%$ of catalyst in $\mathrm{CH}_{2} \mathrm{Cl}_{2}$ at $0{ }^{\circ} \mathrm{C}$; ${ }^{\mathrm{b}}$ Isolated yields; ${ }^{\mathrm{c}}$ In all cases ee was determined by HPLC using a chiral column (Chiralcel OD), unless otherwise mentioned; ${ }^{\mathrm{d}}$ Determined by GC on chiral Cyclodex- $\beta{ }^{\mathrm{e}}$ Determined by HPLC on Chiralpak AD; ${ }^{\mathrm{f}}$ Absolute configurations were $R$, which were determined by comparing the sign of optical rotations with those in literature. 
<smiles>O=Cc1ccccc1</smiles><smiles>O=Cc1c(Cl)cccc1Cl</smiles>

$7 a$<smiles>N#Cc1ccc(C=O)cc1</smiles>

$7 g$
$7 \mathbf{b}$<smiles>O=Cc1ccc(Cl)cc1</smiles>

7h<smiles>O=Cc1ccccc1Cl</smiles><smiles>COc1ccccc1C(=O)Cl</smiles>

7c<smiles>O=Cc1ccccn1</smiles><smiles>O=C/C=C/c1ccccc1</smiles>

$7 n$<smiles>COCCOCc1ccccc1</smiles>

70<smiles>O=Cc1ccc(F)cc1</smiles>

$7 \mathbf{i}$
$7 d$<smiles>COc1ccc(C=O)cc1</smiles>

$7 \mathbf{j}$<smiles>Cc1cccc(C=O)c1</smiles>

$7 f$

$7 m$

In short, an efficient catalytic enantioselective oxa-HDA reaction of Danishefsky's diene and aldehyde utilized $\mathrm{H}_{8}$-BINOL-Ti $\left(\mathrm{O}_{i} \mathrm{Pr}\right)_{4}$ in presence of $4 \AA$ MS has been developed. The oxaHDA reaction can be performed under mild conditions in excellent isolated yields and ee values with the easily prepared ligand $\mathrm{H}_{8}$-BINOL. Further efforts would be directed toward new catalysts for high enantioselective HDA reaction of ketones.

All results above indicate that chiral titanium complexes are perspective catalysts for many asymmetric reactions with promising enantioselectivities. We have enriched titanium methodology and extended it to the asymmetric silylcyanation of aldehydes, oxidation of sulfides, hetero-Diels-Alder reaction, and trimethylsilylcyanation of ketones.

\section{Acknowledgements}

This article was dedicated with best wishes to Professor Zhi-Tang Huang on the occasion of his 75th birthday. We are grateful to the National Natural Science Foundation of China (No 20072037, 29832020, 29602007) and the Ministry of Education, P.R. China for financial support.

\section{References and Notes}

1. For general reviews, see: (a) Jacobsen, E. N.; Pfaltz, A.; Yamamoto, H. In Comprehensive Asymmetric Catalysis; Springer: New York, 1999. (b) Ojima, I. In Catalytic Asymmetric Synthesis; $2^{\text {nd }}$ ed.; Willey: New York, 2000. (c) Lin, G.-Q.; Chen, X.-Z.; Li, Y.-M. In Principle and Application of Asymmetric Reactions; Science Press: Bejing, 2000 (in Chinese). (d) Berrisford, D. J.; Bolm, C.; Sharpless, C.B. Angew. Chem. Int. Ed. 1995, 34, 1059. 
2. For general review, see: (a) Bradley, D. C.; Methrotra, R. C.; Gaur, D. P. In Metal Alkoxides; Academic Press, London, 1978. (b) Clark, R. J. H. In The Chemistry of Titanium and Vanadium, Elsevier, Amsterdan, 1968. For other related asymmetric reactions, see: (c) Feng, X.-M.; Shu, L.-H.; Shi, Y. J. Org. Chem. 2002, 67, 2831. (d) Feng, X.-M.; Shu, L.H.; Shi, Y. J. Am. Chem. Soc. 1999, 121, 11002. (e) Long, J.; Hu, J.; Shen, X.; Jiang, B.; Ding, K.-L. J. Am. Chem. Soc. 2002, 124, 10.

3. Shen, Y.-C.; Feng, X.-M.; Jiang, Y.-Z. Chin. J. Org. Chem. 2001, 21, 944(in Chinese).

4. (a) Jiang, Y.-Z.; Zhou, X.-G.; Hu, W.-H. Tetrahedron: Asymmetry 1995, 6, 405. (b) Pan, W.-D.; Feng, X.-M.; Gong, L.-Z.; Hu, W.-H.; Li, Z.; Mi, A.-Q.; Jiang Y.-Z. Synlett. 1996, 337. (c) Jinag, Y.-Z.; Gong, L.-Z.; Feng, X.-M.; Hu, W.-H.; Li, Z.; Mi, A.-Q. Tetrahedron 1997, 53, 14327. (d) Feng, X.-M.; Gong, L.-Z.; Hu, W.-H.; Li, Z.; Pan, W.-D.; Mi, A.-Q. ; Jinag, Y.-Z. Chem. J. Chin. Univ. 1998, 19, 1416 (in Chinese)

5. (a) Peng, Y.-G.; Feng, X.-M.; Yu, K.-B.; Li, Z.; Jiang, Y.-Z.; Yeung, C.-H. J. Organomet. Chem. 2001, 619, 204. (b) Peng, Y.-G.; Feng, X.-M.; Cui, X.; Li, Z.; Jiang, Y.-Z.; Chan, A. S. C. Synth. Commun. 2001, 31, 2287. (c) Peng, Y.-G.; Feng, X.-M.; Wang, B.; Li, Z.; Yang, G.-S.; Jiang, Y.-Z. Chem. J. Chin. Univ. 2001, 22, 223 (in Chinese). (d) Peng, Y.-G.; Feng, X.-M.; Cui, X.; Jiang, Y.-Z. Chem. J. Chin. Univ. 2001, 22, 1326 (in Chinese). (e) Peng, Y.-G. Ph. D. Thesis, Chinese Academy of Sciences, Chengdu, 2001 (in Chinese).

6. (a) Wang, B.; Feng, X.-M.; Cui, X.; Liu, H.; Jiang, Y.-Z. Chem. Commun. 2000, 1605. (b) Wang, B.; Feng, X.-M.; Huang, Y.-Z.; Cui, X.; Jiang, Y.-Z. J. Org. Chem. 2002, 67, 2175.

7. (a) Shen, Y.-C.; Feng, X.-M.; Li, Y.; Zhang, G.-L.; Jiang, Y.-Z. Synlett. 2002, 793. (b) Shen, Y.-C.; Feng, X.-M.; Zhang, G.-L.; Jiang, Y.-Z. Synlett. 2002, 1353. (c) Shen, Y.-C. Ph. D. thesis, Chinese Academy of Sciences, Chengdu, 2002 (in Chinese).

8. Gregory, R. J. H. Chem. Rev. 1999, 99, 3649.

9. Hyashi, M.; Inuoe, T.; Oguni, N. J. Org. Chem. 1993, 58, 1515.

10. Liu, B.; Feng, X.-M.; Chen, F.-X.; Zhang, G..-L.; Jiang, Y.-Z. Synlett 2001, 1551.

11. Carreno, M. C. Chem. Rev. 1995, 95, 1717.

12. (a) see: 5a-d, and references cited therein. (b) Brunel, J. M.; Diter, P.; Duetsdch, M.; Kagan, H. B. J. Org. Chem. 1995, 60, 8086.

13. Bolm, C.; Khanh Luong, T. K.; Harms, K. Chem. Ber. Recueil. 1997, 130, 887

14. Kamatsu, N.; Hashizume, M.; Sugita, T.; Vemura, S. J. Org. Chem. 1993,58, 7624.

15. (a) Belokon, Y. N.; Green, B.; Ikonnikov, N. S.; North, M.; Tararov, V. I. Tetrahedron Lett. 1999, 40, 8147. (b) Belokon, Y. N.; Green, B.; Ikonnikov, N. S.; North, M.; Parsons, T.; Tararov, V. I. Tetrahedron 2001, 57, 771. (c) Hamashima, Y.; Kanai, M.; Shibasaki, M. J. Am. Chem. Soc. 2000, 122, 7412.

16. (a) Shibasaki, M.; Yoshikawa, N. Chem. Rev. 2002, 102, 2187. (b) Yabu, K.; Masumoto, S.; Yamasaki, S.; Hamashima, Y.; Kanai, M.; Du, W.; Curran, D. P.; Shibasaki, M. J. Am. Chem. Soc. 2001, 123, 9908. (c) Hamashima, Y.; Kanai, M.; Shibasaki, M. J. Am. Chem. Soc. 2000, 122, 7412.

17. Tian, S.-K.; Deng, L. J. Am. Chem. Soc. 2001, 123, 6195. 
18. Deng, H.; Isler, M. P.; Snapper, M. L.; Hoveyda, A. H. Angew. Chem. Int. Ed. 2002, 41, 1009.

19. For general review, see: (a) Danishefsky, S. J. Acc. Chem. Res. 1981, 14, 400. (b) Jørgensen, K. A.; Johannen, M.; Yao, S.; Audrran, H. Thorhauge J. Acc. Chem. Res. 1999, 32, 605.

20. Keck, G.; E.; Li, X.-Y.; Krishnamurthy, D. J. Org. Chem. 1995, 60, 5998. 